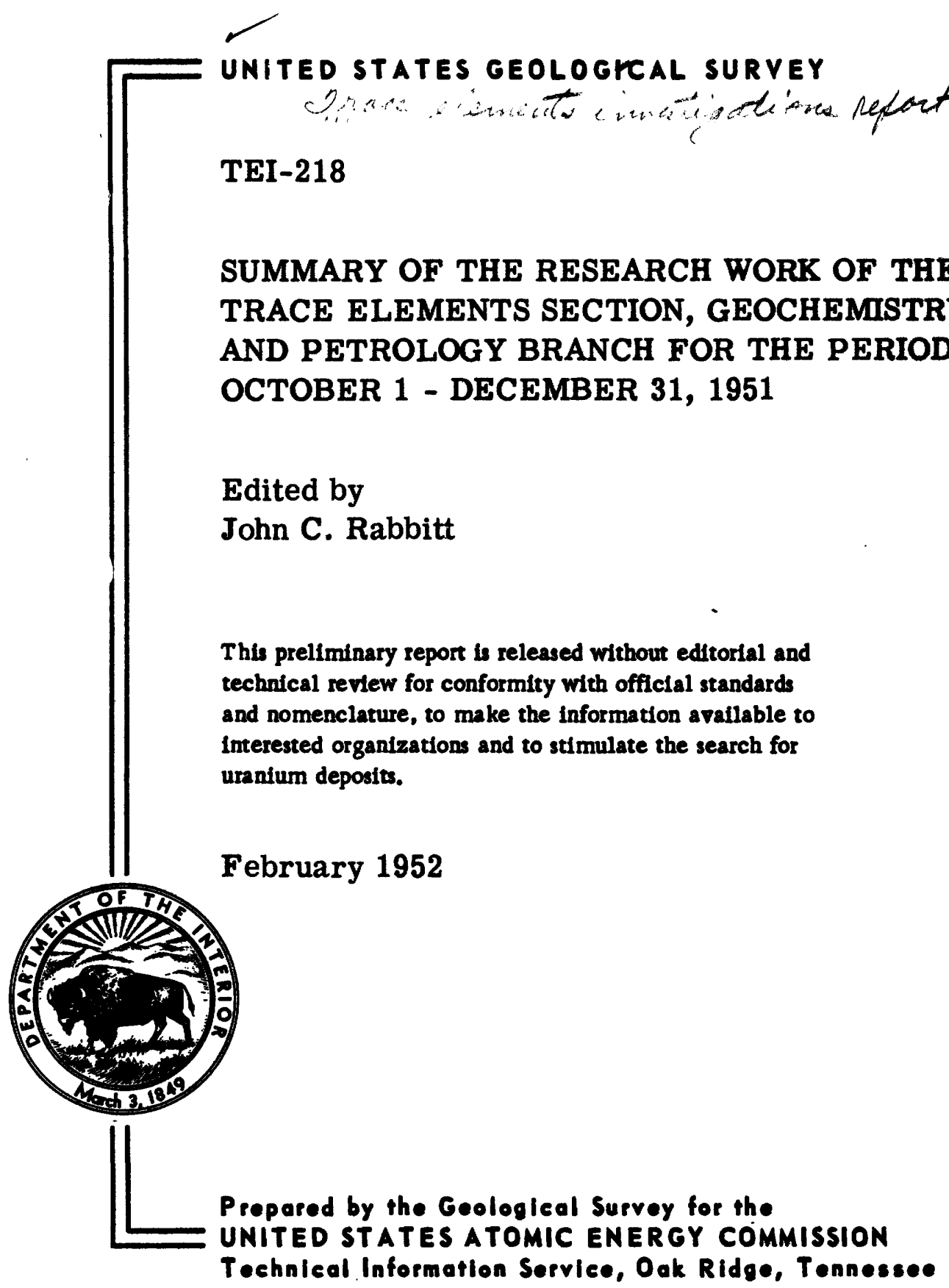


In an effort to save you and your government time and money, this report has been reproduced direct from copy as submitted to the Technical Information Service. 
UNITED STATES DEPARTMENT OF THE INTERIOR

GEOLOGICAI SURVEY

SUMMARY OF THE RESEARCH WORK OF THE TRACE EIEMEETS SECTION, GEOCHEMISTRY AND PETROLOGY BRANCH, FOR THE PERIOD OCTOBER 1 - DECEMBER 31, 1951 *

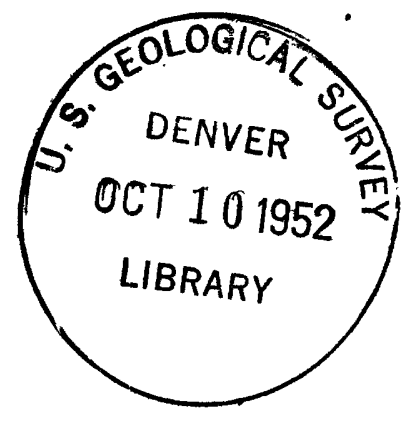

Trace Elements Investigations Report 218

\section{1}

* This report concerns work done on behalf of the Divisions of Raw Materials and Research of the U. S. Atomic Energy Commission. 
SUMMARY OF THE RESEARCH WORK OF THE TRACE ELEMENTS SECTION, GEOCHEMISTRY AND PETROLOGY BRANCH, FOR THE PERIOD OCTOBER 1 - DECEMBER 31, 1951

Edited by

John C. Rabbitt

ABSTRACT

The research of the Trace Elements Section, Geochemistry and Petrology Branch, is summarized for the period October 1 - December 31, 1951. The research work consists of (1) mineralogic, petrologic, and geochemlcal investigations of radioactive rocks, minerals, ores, and waters; (2) fundamental research in the geochemistry of uranium; (3) investigations of chemical methods of analysis for uranium, thorium, and other elements and compounds in radioactive materials, and related chemical problems; (4) investigations of spectrographic methods of analysis for a wide variety of elements in radioactive materials; (5) investigations of radiometric methods of analysis as applied to radioactive materials.

\section{INTRODUCTION}

This report summarizes the research work of the Trace Elements Section, Geochemistry and Petrology Branch, for the period October 1 December 31, 1951. Earlier summaries, with similar titles, have been issued in this same series under numbers 148-A (June 1951), 151 (May 1951), 167 (September 1951), 182 (November 1951). 
The research work of the Section consists of the following laboratory and related field studies:

1. Mineralogic, petrologic, and geochemical investigations of radioactive rocks.

2. Fundamental research in the geochemistry of uranium.

3. Investigations of chemical methods of analysis for uranium, thorium, and other elements and compounds of radioactive materials, and related chemical problems.

4. Investigations of spectrographic methods of analysis for a wide variety of elements in radioactive materiais.

5. Investigations of radiometric methods of analysis as applied to radioactive materials.

Progress was made during the quarter on all phases of the studies mentioned above. Some examples of this progress (described in more detail in the text) are the accumulation and evaluation of much analytical data on uraniferous lignites; intensification of work on the distribution of uranium in igneous rocks; accumulation and evaluation of additional isotopic data on the problem of the geologic age of the Colorado Plateau ore deposits; completion of a combined chemical - spectrograph method for the determination of individual rare earths in phosphate rocks completion of an investigation of the volatility or non-volatility of germanium during the ashing of lignites up to $1000 \mathrm{C}$; a reorganization of projects under investigation by the Radioactivity Unit; progress in the precise spectrographic determination of lead in zircon. 


\section{MINERALOGIC AND PETROLOGIC INVESTIGATIONS}

\section{Introduction}

The mineralogic and petrologic investigations of the Section, under the direction of Theodore Botinelly, are organiced in the following projects:

1. The phosphate project

2. The Colorado Front Range project

3. The Colorado Plateau project

4. The properties of uranium minerals project

5. The lignite project

6. Miscellaneous projects

The laboratory work is supplemented by field work by members of the Section and it is closely coordinated with the work of the resident fleld geologists in the areas studied.

The phosphate project

by

Z.S.Altschuler

No work was done during the quarter on the mineralogy and petrology of the leached zone and underlying material and the "hardrock" deposits of the Florida phosphates.

Work was in progress during the quarter on separation, indentification and testing of minerals in several suites of rock from the 
Phosphoria formation of the northwest. It is hoped, in addition to identifying the major and minor constituents of the rocks, to establish the level of uranium content of the nonphosphatic constituents. In view of the fine interlaminations of mudstone and phosphate that are common in the phosphate zones it is possible to identify the clays present throughout the zones studying the siltstone members. Thus far, hydromica has been identified from material near Fort Hall, Idaho, and kaolin and hydromica are present near Leef, Wyoming.

In cooperation with Roger Swanson, resident field geologist, and F. S. Grimaldi, Head of the Chemistry Unit, a comparative study was made of analytical results on some thousands of samples analyzed in the Denver and Washington Laboratories of the Section and the Bureau of Mines Laboratory at Albany, Oregon. Several lots of samples have been duplicated in all three laboratarles. Some concern has arisen over differences in $\mathrm{P}_{2} \mathrm{O}_{5}$ results in the three laboratories.

It was found that the modal difference in $\mathrm{P}_{2} \mathrm{O}_{5}$ as determined by the three laboratories was less than 0.5 percentage points; however, as the distribution of differences is far from normal, it may be misleading to rely on this or any other average for a picture of the deviations. It can be said, however, that more than 80 percent of the analyses have differences of less than 1.3 percentage points; 90 percent have differences of less than 2.0 percentage points; and 95 percent have differences of less than 2.5 percentage points. The remaining 5 percent shows a discontinuous distribution of single differences and probably represents the number of expectable blunders. It should be noted that the differ- 
ences reflect the sum of all possible deviations arising from splitting and handling of samples and chemical analysis.

The report "Further studies of the distribution of uranium in rich phosphate beds of the Phosphoria formation", by M. E. Thompson, is being edited. This report deals with the comparison between uranium content and the content of $\mathrm{F}, \mathrm{CO}_{2}$, and $\mathrm{P}_{2} \mathrm{O}_{5}$ of five sets of small contiguous samples. In two sets of samples a good correlation exists between uranium and each of the other constituents. In addition to the chemical comparisons the correlation between uranium content and size and sorting of phosphate pellets was also studied for two sets of samples. The modal grain size shows the best correlation with uranium content but none of the correlations obtained is very good.

Work was done during the quarter on the carbonate-apatite problem. One of the points of contention among workers in this field is whether minor amounts of calcite, occluded in apatite, can be detected by X-ray means. It has been shown by Sol Silverman (U. S. Geological Survey Trace Elements Investigations Report 118, August 1951) that as little as 3 percent of calcite in apatite can be detected. In one sense, however, even this figure is not pertinent. Thus, if calcite is present as an inclusion in carbonate-apatite, it must be of submicroscopic size as it cannot be seen through the petrographic microscope. It is therefore valid, when making mixtures for testing the limits of $\mathrm{X}$-ray detection of calcite in apatite, to grind the calcite to a considerably fin slze. than the apatite with which it is mixed. Such a procedure was tested. Calcite ground to - 400 mesh was mixed with pure fluorapatite ground to 


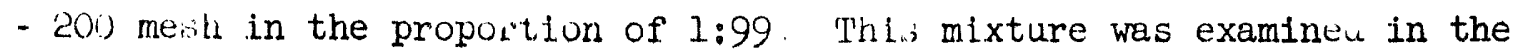
$X$-ray spectrometer at different spectrometer settings. In the resulting patterns the strongest peak for calcjte was at a peak of small amplitude. Thus, one percent of calcite mixed with fluorapatite can be detected if the calcite is ground finer than the apatite and the peak amplitudes of the $X$-ray spectrometer are sufficiently magnified.

$X$-ray studies of the apatites are continuing. The demonstration of the unfqueness of carbonate apatite has already been reported (Trace Elements Investigations Report 118). However, work is now being done on the indexing of films and calculation of cell constants so that the differences among the hydroxl- and fluorapatite end members and carbonatefluorapatite can be quantitatively stated.

The work on phosphates from Morocco is described in "The petrography and uranium content of phosphates from Morocco", by Z. S. Altschuler (U. S. Geological Survey Trace Elements Memorandum Report 238, December 1951). The abstract follows:

The phosphates of Morocco occur as beds of friable, pelletal carbonate-fluorapatite in a sequence of Eocene limestones, marls and cherts. Each ore bed is overlain by well-indurated, moderately phosphatic material. The samples studied are representative of the bed that is being mined, other phosphate beds and the overburden in the Khouribga deposits (those of the Oulad-Abdoun basin).

The mined and minable beds are very rich in $\mathrm{P}_{2} \mathrm{O}_{5}$, containing 31.0 to 33.6 percent $\mathrm{P}_{2} \mathrm{O}_{5}$, equivalent to 75 to 80 percent apatite. Their uranium content ranges from 0.011 to 0.022 percent. No uranium minerals were found. Only minor amounts of clay (montmorillonite), quartz, chert, and calcite are present. None of these in pure state contains more than 0.001 percent uranium.

The overburden samples consist of phosphatic limestone, chert, and clay. They range in $\mathrm{P}_{2} \mathrm{O}_{5}$ content from 6.8 to 15.8 percent and in uranium content, which is proportional to their apatite content, from 0.004 to 0.008 percent. 
No evidence of secondary concentration of uranium was found in any of the samples. Mineralogic alteration is lacking; uranium content, although relatively high, is not unusually so and is uniform within a particular sample, and the materials are in radioactive equilibrium.

In contrast to other phosphorites the Moroccan ores are low in trace elements, both in number and amounts present. This reflects mainly the lack of associated detrital minerals.

The phosphate particles are very well rounded and well sorted. The majority of the grains contain radiolarian test fragments, a small percent of them are replaced coprolites or bone fragments, and the remaining 40 percent do not contain fossil remains. It is believed that the phosphorites originated mainly as primary replacements of, and precipitations around, radiolarian and other fossil debris, and that the overburden rocks are results of changing lithologic conditions during original deposition.

The Colorado Front Range project

by

George Phair

Analyses (radiometric and chemical uranium) on 130 samples collected during the 1951 field season in the Colorado Front Range have been completed. Most of these are from the Central City district and the new analyses confirm earlier results. Standard rock analyses of ne: quartz monzonite, two unaltered quartz bostonites, and one hydrothermally bleached quartz bostonite, all from the Central City district, have been obtained. A summary report on the work in the Central City district is in preparation.

Additional samples of radioactive material were collected from the Wood and Kirk mine dumps on Quartz Hill near Central City. Previous 
work has suggested that the dump material was characterized by an excesively high $\mathrm{Ra} / \mathrm{U}$ ratio but that this abnormal ratio was approximately constant for separate samples from the same "hot spot" regardless of the uranium content of the sample. The indications were that this constant but excessive $\mathrm{Ra} / \mathrm{U}$ ratio could be used to give a quantitative estimate of the amount of uranium lost through recent leaching. New analyses are planned to check this tentative conclusion. A report on this subject will be prepared in the late spring of 1952.

Hard pitchblende was hand-picked in the laboratory from high-grade ore samples from the Copper King mine, Larimer County, Colorado, and the chemical work for age determinations is now in progress. Also in progress are uranium, thorium, and lead determinations on cyrtolite and monazite from pegmatites associated with the surrounding granite. The field evidence strongly indicates that the deposition of the earlier, high temperature (?) sulfides in this deposit was related to the intrusion of the surrounding granite. The pitchblende was introduced the the fracturing of the earlier replacement (?) ores, and preliminary chemical results suggest a maximum age of Tertiary for the pitchblende. Similar age determinations on uraninite crystals now being separated from a preCambrian (?) granite from the Central City district are planned. This uraninite has ail the appearances, at least, of a primary accessory mineral in the granite and occurs only a few hundred feet from the iron vein which carries colloform pitchblende for which an age of 65 million years $\left(\mathrm{Pb}^{206} / \mathrm{U}^{238}\right.$ ratio) has been determined (see Trace Elements Memorandum Report 317 by Lorin Stieff and Tom Stern). 
These age studies will be of great significance in determining the paragenesis of the Colorado Front Range deposits and they are being undertaken in cooperation with Lorin Stieff and Tom Stern of the isotope geology project.

No work was done during the quarter on the radioactive fluorites from the Front Range and none is planned for the immediate future.

Kyoko Shimamoto continued studies of the minerals of the radioactive cerite deposit near Jamestown, Colorado. Most of the uranium in the samples studied is associated with the rarearth phospho-silicate, britholite, the properties of which were discussed in the preceding quarterly report. The thorium present is distributed among britholite, bastnaesite, and monazite and is present only as a trace in allanite.

\section{The Colorado Plateau project}

\section{Alice Weeks and Leonard Riley}

In the mineralogic and petrologic studies of the Colorado Plateau deposits rauvite has been identified as a red coating on and apparently as an alteration product of tyuyamunite in ore samples from the Arrowhead mine, Mesa County, Colorado. More than a gram of rauvite was sepa: rated from a rich ore sample from Monument No. 2 mine, Arizona, and chemically analyzed. The formula deduced from this analysis agrees with that of the original description, $\mathrm{CaO}^{\circ} 2 \mathrm{UO}_{3}{ }^{\circ} 6 \mathrm{~V}_{2} \mathrm{O}_{5}{ }^{\circ} 2 \mathrm{OH}_{2} \mathrm{O}$. The water content waries and the color is generally lighter than originally described (Frank 
Hess, U. S. Geological Survey Bulletin 750, 1925). In the Arizona material rauvite is associated with yellow-orange material, probably representing the transition stage between tyuyamunite and rauvite, and with corvusite. The lead content of the rauvite is very low, indicating a geologic age of probably less than 10 million years, and the rauvite is probably a recent alteration product.

A pale-green efflorescent mineral associated with zippefe in the Happy Jack mine, White Canyon, Utah, has been identified as jofnnite. "Cobalt bloom" minerals from this area include cobaltoan pickeringite from the Scenic No. 4 claim and erythrite and pale-pink cobaltoan siderotil from the Happy Jack mine. The latter of these occurs with pyritized wood and the erythrite occurs with pyrite crystals in a thin shale layer containing no fossil wood.

Alunite has been identified in mate from the Anaconda claims in Red Canyon, Utah, where chalcopyrite, covellite, antlerite, and chalcanthite were also identified.

Many clay samples have been studied in connection with the following problems:

1. Gray clay from ore of five different mines in the Shinarump conglomerate shows no montmorillonite in the X-ray spectrometer graphs although the formation is thought to contain some montmorillonite outside of ore deposits (according to some of the field geologists).

2. The problem of "altered" clay under ore zones has continued to be studied by means of X-ray, chemical, petrographic, and elec- 
tron microscope analysis of samples carefully collected (July 1951) from close to color boundaries tween red and gray clay. A report on these studies is in preparation.

3. X-ray spectrometer studies of mudstone and siltstone samples have been made in cooperation with Aaron Waters and Robert Cadigan of the Survey who have been using the benzidine test in the field to identify montmorillonite. An effort is being made to determine the sensitivity of each method (X-ray and benzidine) and reasons for non-agreements.

4. In the X-ray study of "vanadium clay" samples, a few have been found to contain a conspicuous amount of chlorite. Further work will be done on the origin and composition of this chlorite.

A summary of the clay studies to date was being prepared at the end of the quarter by Weeks for presentation at the conference on the Plateau deposits Grand Junction, January 6, 1952.

Riley spent much of the quarter in a preliminary study of the distribution of elements in the uranium ores of the Plateau in cooperation with E. M. Shoemaker. Mill pulps representing about 5,000 tons of ore were obtained and combined to give 59 samples for semiquantitative spectrographic analysis. Also, 40 mill pulp samples, collected for isotope study, were similarly analyzed. These were chosen to give both geographic and stratigraphic distribution. For comparison, suites of samples of igneous rocks, sandstones, and their heavy minerals, shales, and mineral deposits of importance for ore other than uranium were also included. 
The spectrogiaphic results were studied with particular regard to the geographic location of the samples. Besides vanadium, (available from production records) $\mathrm{Zn}, \mathrm{Co}, \mathrm{Ni}, \mathrm{Pb}, \mathrm{Cu}$, and $\mathrm{Ag}$ showed correlations to uranium. $\mathrm{TI}, \mathrm{Cr}, \mathrm{Zr}$, and $\mathrm{B}$ are apparently largely contained in the detrital minerals of the sediments. Metals of uncertain affinities are $\mathrm{Be}, \mathrm{As}$, and Mo. The distribution of zinc is marginal to the ore districts rather than in direct relation to the uranium. The results were embodied in a paper to be given at the conference on the Plateau deposits in Grand Junction, January 6, 1952.

It is planned to enlarge this study by further sampling of mill pulps and related material.

A summary report of the mineralogy of the Plateau deposits will be prepared in the late spring of 1952.

No work was done on wall-rock alteration in the Plateau deposits during the quarter.

\section{The properties of uranium minerals project}

$$
\text { by }
$$

Joseph Berman and John C. Rabbitt

Studies of metamict minerals by Berman continued during the quarter. Much of the time was spent on calculations for indexing the various $\mathrm{X}$-ray powder patterns that result when metamict minerals are heated under controlled conditions and as a consequence become crystalline. This study has revealed structural changes that occur when certain minerals, 
fergusonite for example, are heated at different temperatures.

When metamict fergusonite, is heated to approximately $500 \mathrm{C}$ crystallization occurs. The initial crystallization results in crystal axes forming an orthogonal lattice with parameters of $a_{0}=5 / 9 \mathrm{~A}, b_{0}=11.02 \mathrm{~A}$, $c_{0}=5.51 \mathrm{~A}$ and $a: b: c=0.471: 1: 0.500$. The $b$ - axis is exactly twice the length of the c - axis. However, attempts to index the powder pattern in conformance with a tetragonal lattice were unsuccessful.

On heating the same material to about $850 \mathrm{C}$ it undergoes a structural change to a lattice with higher symmetry. This lattice is tetragonal with parameters $a_{0}=7.72 \mathrm{~A}, c_{0}=11.29, c / a=1.46$. This agrees closely with results reported by Barth I/ on fused fergusonite, and synthetic fergusonite. Apparently Barth mistakenly assumed that metamict fergusonite crystallized in the same manner whatever the temperature. He also made the possibly true but unproved assumption that fusing together equimolecular amounts of $\mathrm{Y}_{2} \mathrm{O}_{3}$ and $\mathrm{Nb}_{2} \mathrm{O}_{5}$ would produce crystalline fergusonite. No doubt exystalline $\mathrm{YNbO}_{4}$ is produced but it is still uncertain whether the resulting material is equivalent to originally crystalline fergusonite.

Work with metamict euxenite discloses similar crystal-structural differences resulting from different temperatures and atmospheres during heating. The ease of formation of structural analogues in these and other metamict niobate-tantalate minerals may aid in explaining why these minerals are so commonly metamict.

I/ Barth, Tom, The structure of synthetic, metamict, apd recrystallized fergusonite: Norsk geol. tidsskr., IX, 1926. 
A selected bibliography on metamict minerals is being prepared by Theodore Botinelly.

Work progressed on the monograph on the "Mineralogy of uranium" under the editorship of Rabbitt. Clifford Frondel of Harvard University is writing the chapter on description of properties; Judith Frondel is preparing a number of descriptive tables; George Switzer of the National Museum is writing chapters on the occurrence and association and the geographic location of uranium minerals; Theodore Botinelly is writing a chapter on characteristic methods of identifying uranium minerals in the field and laboratory. A conference of these people to assay progress is scheduled for early in February 1952.

Toward the last of the quarter the edition of 2,500 copies of "A Glossary of Uranium- and Thorium-bearing Minerals", by Judith Weiss Frondel and Michael Fleischer (U. S. Geological Survey Circular 74, April 1950) was nearing exhaustion. A new and revised edition with corrections and additions is being prepared and is scheduled prompletion in the next quarter.

\section{The lignite project}

$$
\text { by }
$$

Maurice Deul

As was mentioned in the two preceding quarterly reports (Trace Elements Investigations Report 167 and Trace Elements Investigations Report 182) Maurice Deul is coordinating information developed in the coopera- 
tive work on lignites eing carried on in the Survey under the direction of Norman Denson for 'he Fuels Branch projects in the field, James M. Schopf for the Fuelsi Branch Coal Geology Laboratory in Columbus, Ohio, and Maurice Deul for the Trace Elements Section Washington Laboratory. The distribution of effort in these three groups is described in Trace Elements Investigations Report 182. In addition Farrington Daniels of the University of Wisconsin, Donald Peppard of the Argonne National Laboratory, and Keith Brown of the Oak Ridge National Laboratory are interested in different aspects of the work.

Deul is preparing a summary report on the work on lignites undertaken to date by the Washington Trace Elements laboratory, the Coal Geology Laboratory in Columbus, and the field geologists. This will be an informational report containing details of analytical results to an extent that cannot be duplicated here. However, in advance of the issuance of the report some of the high-lights of the work are given here.

The Dakota lignites have received the most detailed investigation to date of all the different lignites. The last 2 of 19 holes were cored during the quarter, the drilling being completed on November 2l, 1951. These holes, on Slim Buttes in Harding County, South Dakota, almost 400 feet deep, were drilled through the Arikaree and White River formations to the lignite beds below. This will permit comparison of analyses of these relatively fresh lignites with lignite from the same beds previously cored from sites on the flanks of the butte.

Cored coals from three holes (nos.17, 18, and 19) were sampled and 
megascopic characteristics described at Schopf's laboratory and from these cores 48 samples were selected and sent to the Trace Elements Section Washington Laboratory for analysis and 11 samples were sent to the Bureat. of Mines for analysis. Thin sections of the lignite were prepared from such samples as were physically suitable and detailed examination and a description of the microscopic characteristics will be completed when the entire suite of thin sections has been prepared.

The Bureau of Mines Coal Analysis Section completed analyses of 12 samples of cored coals. These were proximate analyses plus determination of sulfur, calorific value, and ash fusibility. One sample in addition received an ultimate analysis.

Analytical work performed on lignite in the Section consists mainly of equivalent percent uranium, chemical percent uranium and ash determinations; 86 core samples were so analyzed during the quarter. Complete semiquantitative spectrographic analyses on 93 samples of ashed lignites were reported. Special analytical work was performed on three samples of powdery lignite from core hole No. 8 and analyses on 9 samples from Sentinel Butte in Golden Valley County, North Dakota, were analyzed chemically and radiometrically.

Other Fuels Branch lignite projects were operating in the Rocky Mountain States during the quarter and samples were collected by both reconnaissance parties and auger $\triangleleft$ drill crews. A large number of samples were submitted for analysis and listed below are the numbers of samples appropriately analyzed for each of the projects during the quarter: 
Project No. $\quad$ No. of samples analyzed for percent Eq. U., U, ash

568

569

570

571
63

249

199

94
No. sauples, special analysis

11

Samples of lignite ash were reserved from each sample for futire spectrographic analysis. When the initial chemical and field data have been evaluated, the most suitable lignite ashes will be selected for complete semiquantitative spectrographic analysis.

During the quarter 48 samples of lignite from Milam County, Texas, were radiometrically analyzed and moisture and ash content determined. Further analyses were unnecessary because of the low radioactivity of these samples. Three samples from the Boukal-Noonan mine in McKenzie County, North Dakota, were completely analyzed for ash, uranium, and trace-element content; these samples contained less than 0.001 percent uranium in the ash but are of interest for comparison with the uraniferous lignites found farther south.

A suitable method of preparing nuclear stripping films on thin sections of lignite is under investigation. Special difficulties arise from the fact that the sections craze rapidly when exposed to air and hence the surface of the coal must always be kept moist.

A flat-plate X-ray diffraction camera with multi-purpose collimators and sample holders has been obtained for use in investigating the crystallinity and as an aid to the identification of the waxy and resinous components of lignite. The camera is being standardized and techniques for the extraction of the components are being investigated. 
Methods of uranium and thorium analysis

Colorimetric and fluorimetric reagents for the rapid determination of thorium, by Mary Fletcher and F.S.Grimaldi.--Seventeen compounds, including six prepared in the Washington Laboratory, were tested as possible reagents for the determination of thorium, and found to be unsatisfactory because of lack of specificity: More reagents are being tested.

Fluorimetric determination of uranium in saline and nonsaline waters, by Audrey Pietsch and F.S. Grimaldi.--This investigation was completed during the quarter and a report on the work is in process. The tentative abstract of the report is as follows:

The procedure determines about $10^{-8}$ percent U using 500-m samples of water. Uranium is concentrated by precipitating uranyl phosphate using aluminum phosphate as a carrier. The aluminum phosphate is dissolved in nitric acid, salted with aluminum nitrate, and the uranium is extracted with ethyl acetate. A portion of the ethyl acetate is evaporated in a standard platinum dish and a fluorescing disc is prepared with a mixed fluoride flux. Fluorescence measurements are made with a fluorimeter. One precipitation of $\mathrm{AlPO}_{4}$ collects more than 95 percent of the uranium. Samples of ocean water tested contain about $3 \times 10^{-7}$ percent uranium.

Studies of critical factors in the fluorimetric determination of uranium, by Mary Fletcher.--It had been previously established by work in the Section's Washington Laboratory that overheating in the preparation of fluoride melts resulted in serious quenching of the uranium fluorescence. This was found to be caused by the dissolution by the flux of platinum from the containers. It was expected that old containers would be more resistant to attack by the flux (from repeated use one would expect that the easily soluble parts of the containers would have already been removed). 
that were obtained from the Mass Assay Laboratory, Oak Ridge, of these seven samples revealed substantial variations in the isotopic composition of the lead -- rather systematic variation from nucleus toward the outer growth zones. Two more samples have since been cut from the same crystal and submitted for isotope analysis as a check on the, first results. When the two additional analyses are received, a brief report will be prepared to summarize these results and interpret their significance.

Study of X-ray methods by Charles L. Christ

Staffing of this project and purchase of equipment progressed during the quarter. It is expected that the staff will be obtained in the first half of 1952.

Much of the equipment for the project has been obtained and put in working order.

\author{
CHEMICAL INVESTIGATIONS
}

Methods of analysis project

Fluorimetry

by

Irving May and Mary Fletcher

Work continued in fluorimetry in the Washington Laboratory, consisting of making minor modifications to existing instruments to make them more compact, stable, and versatile. 
first steps in this project are to plan the Iine of attack and whe selection of suitable materials for investigation, to collect sample materials under geologically controlled conditions, and to investigate sampling hazards peculiar to this investigation. Progress of this work from July through December 1951 is reported here.

Considerable planning and some field investigation and collection of sample materials had been in progress over a period of several years prior to formal inception of the project. Further field work was carried on intensively during July and August when approximately 150 samples of materials were collected for this work from various sites from Pennsylvania to British Columbia in addition to about 100 samples that had been collected earlier from other localities.

In September and October a. first attempt was made to investigate the feasibility of collecting a sample of lead from raw sea water by extraction as lead dithizonate in organic solvent. As the results of this attempt were inconclusive, a more systematic study was started in December on the problem of extracting lead from sea water for isotope analysis. This study is described under Methods of analysis for miscellaneous elements and compounds, in this report.

A first step in investigating sampling hazards was to sample a single crystal of a lead mineral to test whether the crystal is isotopically homogeneous throughout as has been tacitly assumed in prior work. A large crystal of galena was sawed in half and etched to reveal the concentric growth layers. Seven samples were cut from this etched surface, in sequence, from the nucleus to the outer crystal face. Isotope analyses 
and laboratory data so that a satisfactory hypothesis of origin of these ores may be established. To place this laboratory study on a firmer statistical basis, ages are being determined by the lead-uranium and lead-lead methods on numerous additional carefully selected samples.

A condensed version of it will be presented at the New York meeting of the American Institute of Mining and Metallurgical Engineers in February. An extended description of the isotope work to date was being prepared at the end of the quarter for presentation at the forthcoming conference on the Colorado Plateau deposits in Grand Junction, January 6, 1952.

\section{Isotope geology of lead}

\section{by}

\section{Ralph S。Cannon}

Natural variations in the isotopic composition of lead are large and geologically significant. Variations in the radiogenic lead of radioactive materials are fairly well understood so that they provide an accepted basis for interpreting the history of parental radioactive materials, as in the above work on Plateau uranium ores. But variations in the isotopic composition of lead that occurs outside of radioactive materials present quite different problems that are not similarly understood. Systematic study of these variations in ordinary lead was formally initiated in July 1951 as a new project on the isotope geology of lead. Initial objectives are to determine the isotopic composition of original or primeval earth-lead and to investigate the evolution of isotopic composition of lead in various geologic environments during geologic time. The 
quarter or 1952 it is planned to supplement the samples now being studied with about 30 additional samples of ore from the Slick Rock, Lumsden Canyon, and Temple Mountain districts and 10 mil1 pulps from the Rifle and Placerville districts.

Three uraninite samples and one very pure carnotite sample were carefully prepared and sent to $J$. J. Katz of the Argonne National Laboratory. Mr. Katz is going to apply $0^{16} / 0^{18}$ ratio studies to these samples to see whether this method of determining paleotemperatures can be successful for such minerals. If the method is applicable it should be most helpful in determining the temperature of formation of many uranium minerals. The report "A preliminary determination of the age of some Colorado Plateau uranium ores by the lead-uranium and lead-lead methods", by L. R. Stieff, T.W. Stern, and R. G. Milkey is nearing completion. The abstract follows:

A study of the $\mathrm{Pb} / \mathrm{U}^{238}, \mathrm{~Pb}^{207} / \mathrm{U}^{235}$, and $\mathrm{Pb}^{20} 7 / \mathrm{Pb}^{206}$ ages of the Colorado Plateau uranium ores has been undertaken by the U. S. Geological Survey on behalf of the Atomic Energy Commission as one means of determining the origin of these ores. A simplified treatment of the data for 41 ore samples containing more than 0.1 percent uranium gives a mean $\mathrm{Pb}^{206} / \mathrm{U}^{238}$ age of approximately 71 miliion years, a mean $\mathrm{Pb}^{207} / \mathrm{U}^{235}$ age of approximately 82 million years and a mean $\mathrm{Pb}^{207} / \mathrm{Pb}^{206}$ age of 370 million years. The large discrepancy between $\mathrm{Pb}^{206} / \mathrm{J}^{238}$ and $\mathrm{Pb} 207 / \mathrm{Pb}^{206}$ ages may be the result of selective loss of $\mathrm{U} 238$ daughter products or the addition of old radiogenic lead.

Corrections for the selective loss of daughter products which will bring the three ages into agreement will increase the age to approximately 82 million years. Additions of old radiogenic lead will lower the three calculated ages to approximately 60 million years. The published $\mathrm{Pb}^{206} / \mathrm{J}^{238}$ age of approximately 60 million years for the Laramide pitchblende of the Colorado Front Range has been confirmed in the course of this study.

If the ages calculated from these data are close to the true age of the ores, then the uranium was probably introduced into the sediments in late Mesozoic or early Tertiary time. This conclusion differs markedly from earlier conclusions that the uranium ores were formed in the Triassic and Jurassic sediments of the Colorado Plateau during or soon after deposition. Careful study is continuing in order to resolve the uncertainties in interpretation of both field 
disintegrated by weathering. This material is from the same rock body (fresh rock) and shows very little chemical alteration.

Similar work is in progress on material from the lavas of the San Juan Mountains of Colorado and on some of the granitic rocks of New England.

\section{Behavior of uranium during weathering of source materials}

This project is not yet activated and no work was done during the quarter.

\section{Synthesis of uranium minerals}

No work was done on this project during the quarter.

\section{Isotope geology of uranium, thorium,}

and their daughter products

\section{by}

Lorin Stieff and Tom Stern

About 50 of the samples collected during the 1951 field season on the Colorado Plateau have been prepared for age-determination studies. This group includes 5 specimens of galena, 4 uraninites and 6 associated secondary uranium minerals, and about 35 mill pulps from many deposits in both the Shinarump conglomerate and the Salt Wash sandstone. All of the samples have been analyzed spectrographically and chemically for lead. About 20 samples of lead iodide for lead isotope determinations have been prepared and about the same number of samples have been analyzed chemically for uranium. Five lead isotope analyses were received from Oak Ridge National Laboratory during the quarter. During the first 


\title{
Distribution of uranium in igneous rocks
}

\author{
by \\ E. S. Larsen, Jr。
}

The work on the distribution of uranium in igneous rocks has progressed slowly but three petrologists are joining the staff of this project in January 1952 and progress should then be more rapid.

Most of the work thus far has been preliminary in nature. One of the main problems so far attacked has been to determine the significance of the acid-soluble uranium in granitic rocks. A sample of the Rubidou granite of southern California was treated with $1: 1 \mathrm{HCl}$. The original sample contained $3.3 \mathrm{ppm}$ of $\pi$. After leaching the sample contained only $0.4 \mathrm{ppm} U$, indicating that about 85 percent of the uranium in the granite was soluble. Examination of the leached sample shows that most of the dark minerals have been removed. Zircon remained and showed no appreciable attack by the acid. The zircon has been separated from the rock, and the amount of uranium left in the zircon is being determined. Much of the uranium left in the granite after leaching is believed to be in the zircon. The minerals in the original granite have been separated and are being studied to determine the location of the soluble uranium in the granite. Part of it is, no doubt, in minerals such as apatite and biotite and some may be adsorbed or deposited along grain boundaries and fractures. The solution of this problem is most important to future work on this project.

Samples for similar tests have been prepared from the Bonsall quartz diorite from southern California and from other material mechanically 


\section{Miscellaneous projects}

No work was done during the quarter on further studies of phosphate rock from Mona Island, B. W. I.

A report on a study of the crystallography of attapulgite by electron diffraction methods, by John B. Lyons and Elizabath B. Jaffe (see Trace Elements Investigations Report 182, page 20) is being edited.

FUNDAMENTAL RESEARCH IN GEOCHEMISTRY OF URANIUM

\section{Introduction}

A program of fundamental research in the geochemistry of uranium, to be carried on by the Geological Survey on behalf of the Research Division of the Atomic Energy Commission was approved in the early summer of 1951. The program is divided into five projects as follows:

1. Distribution of uranium in igneous rocks.

2. Behavio of uranium during weathering of source materials.

3. Synthesis of uranium minerals.

4. Isotope geology of uranium, thorium, and their daughter products. 5. Study of $\mathrm{X}$-ray methods.

Problems of staffing for these jocts have slowed down the work but toward the end of the quarter enough people had been obtained so that progress should accelerate during the first half of 1952. 
New data indicate that the amount of quenching depends not only on the temperature of heating but also on the age and composition of the platinum container which determines how much metal is dissolved during preparation of the melt.

The possiolidty of using metals other than platinum as flux containers has been investioted. The choice of metals is limited because of the powerful solvent action of the flux. Gald is used in some laboratories and this metal was tested. Time-temperaiure studies indicate that gold is less suitable than platinum as a flux container.

The new data are included in a report now in process as addenda to the earlier report (Trace Elements Investigations Report 130) on this subject.

\author{
Methods of analysis for aluminum \\ and phosphorus
}

The molybdenum blue method for de determination of micro-amounts of $\mathrm{P}_{2} \mathrm{O}_{5}$ in the presence of $\mathrm{As}$ and $\mathrm{Si}$ in sea water, by Henry Mela, Jr., and J.J. Rowe.--During the quarter work on this project condsted of literature searches to make sure that knowledge of all earlier work on this subject is at hand.

\author{
Methods of analysis for miscellaneous \\ elements and compounds
}

Chemical-spectrographic determination of small amounts $(0.001$ percent and more) of individual rare earths in phosphate rocks, by Henry Mela, Jr., and Claude Waring.--Work on this investigation was completed during the 
quarter (see Trace Elements Investigations Report 182, pp. 22-23). The procedure allows the determination of as little as 0.001 percent of each rare earth in phosphate rock with a high degree of precision. A report on this subject is in preparation.

Investigation of methods for concentration and measurement of lead in sea water and marine deposits, by Daniel $R$. Norton. --In the geologic age studies being undertaken under the isotope geology project of the program of fundamental research in the geochemistry of uranium, it is apparent that basic information is needed about isotopic distribution in lead from sea water and in le from marine deposits of different geologic ages.

A project has been started involving the concentration and measurement of lead from sea water and marine deposits, and the preparation of lead iodide from this lead for isotopic analysis.

1. An accurate and sensitive method is needed not only for measuring the lead content of the original material but also for following the progress of the lead concentration or isolation.

It is first necessary to investigate the application of existing methods or to develop new ones which are sufficiently sensitive, accurate, and convenient, Methods bejing tried are:

a) Spectrophotometric

b) Radiometric tracer

c) Polarographic

d) Combination of chemical concentration and final emis sion mass spectrographic measurement.

2. The second consideration is a method for concentrating and isolating enough lead for mass spectrographic analysis without 
introducing significant amounts of lead from reagents, containers, and other sources.

Methods being tried are:

a) Ion exchange columns

b) Coprecipitation with carriers such as strontium carbonate or mercury sulfide.

c) Extraction as dithizonate by organic solvents

d) Electrolytic deposition.

3. After the two problems above have been solved in the laboratory, equipment must be set up for processing of large quantities of sea water,

Contact is being maintained with several oceanographic organizations which cap be of help in the study.

Earlier work done in the Section's Washington Laboratory on the determination of small amounts of lead $(0.1 \mathrm{ppm})$ by microchemical methods will be incorporated into this study.

\section{Quality of analysis project}

Continuing work on this project will be reported only when significant data are at hand.

High-index liquids project

by

Robert Meyrowitz

Fivf of seven complete sets of liquids prepared in July 1950 were restandardized during the quarter. After 15 months the maximum change 
in index of the liquids in the range of $1.74-1.81$ (methylene iodide, arsenic bromide, sulfur was -0.001 . In the range $1.82-2.00$ (arsenic bromide, sulfur, arsenic disulfide) the maximum change in index was -0.004 . The greatest change in index of liquids in this range occurred in the first three months.

Five complete sets pared in January 1951 were restandardized. After nine months the maximum change in index of liquids in the range 1.66 - 1.81 (alpha-bromonaphthalene, arsenic bromide, sulfur) was -0.001 . For liquids in the range $1.82-2.00$ the maximum change was -0.004 .

Seven complete sets prepared in March 1951 were restandardized. At the end of eight months the maximum change was -0.002 for the range $1.66-1.81$ and -0.003 for the range $1.82-2.00$.

A report "A new series of immersion liquids", by Robert Meyrowitz is in process. The abstract follows:

A new series of high-index immersion liquids (1.66-1.81) has been made. $\alpha$-bromonaphthalene and a solution of precipitated sulfur (10 percent) in arsenic tribromide are the end members. The mixing curve is not a straight line. After nine months the maximum change in index was -0.001 . Stable liquids containing $\alpha$-bromonaphthelene, arsenic tribromide, precipitated sulfur, and arsenic disulfide are discussed.

\section{SPECTROGRAPHIC INVESTIGATIONS}

by

Claude Waring, Tennyson Myers, Charles Annell,

Paul Barnett, Helen Worthing, and Jules Stich

Work was done during the quarter on the addition of selenium to the list of elements covered by the semiquantitative method. This addition 
would bring the total to 70 . By the standard method it was found that a minimum of 5 percent of selenium can be detected. This problem will. be studied as time permits.

Standard plates have now been prepared by Jules Stich for 69 elements for use with the Gaertner prism spectrograph in the so-called single-grain method. These standards have been prepared on the basis of I $\mathrm{mg}$ of sample. This method is particularly useful for the analysis of small mineral grains and $\mathrm{X}$-ray powder mounts. It is planned to write a report on the method.

In the studies Claude Waring and Helen Worthing of the determination of trace amounts of lead, duplicate determinations of a Canadian zircon showed 462 and $437 \mathrm{ppm}$. On a sample from the same bottle, C. C. Patterson at the University of Chicago, using Harrison Brown's dilution method, reported $451 \mathrm{ppm}$. A sample of the same material, when treated with aqua regia, ran 310 ppm. A Canadian perthite sample ran 6.7 ppm in the Section laboratory and $5 \mathrm{ppm}$ in Chicago by the isotope dilution method. These results can probably be improved.

The abstract of a forthcoming report titled "A spectrographic method for determining trace amounts of lead in zircon and other minerals," by C. L. Waring and Helen Worthing, follows:

The spectrographic determination of lead in zircon and some other minerals has been mide by the U.S.Geological Survey to provide data in a study of the age of the rocks that contained these particular minerals. Approximately 150 determinations have been made, and one reproducibiut (consisting of 25 observations) has been completed. material used for the reproducibility test was a silica-base standard containing $30 \mathrm{ppm}$ lead. The average of the results was $30.4 \mathrm{ppm}$ lead. On the whole, standard spectrographic 
procedures were appied, including the split-filter method for calibrating the photographic emulsions.

The method is applicable to samples containing from 0.5 to $1,000 \mathrm{ppm}$ lead with an estimated accuracy of from 6 to 10 percent. No chemical separations or concentrations are required. The other minerals tested by the method are apatite, sphene, microlite, allanite, and perthite.

A new set of lead standards is being prepared based on $U$. S. Bureau of Standards standard no. 91, Opal Glass, containing 0.1 percent lead. This has been diluted in different proportions with lead-free $\mathrm{SiO}_{2}$ and the resulting standards are being checked.

Experimental work was done during the quarter by Claude Waring, in cooperation with Wendell Tucker of the Chemistry Und, to determine if germanium volatilizes during ashing of lignites et. $800 \mathrm{C}$. This work was undertaken at the suggestion of Maurice Deul of the Mineralogy Unit. Five lignite samples with differing amounts of germanium were ashed under a variety of conditions up to temperatures of $1000 \mathrm{C}$. Results of this work show that no germanium is lost during ashing of lignite at temperatures up to $1000 \mathrm{C}$. A report on the work by Waring and Tucker will be in preparation in the first quarter of 1952.

Because of the press of other studies no work was done during the quarter on the detemination of thorium in samples high in uranium (Claude Waring, Charles Annell, Helen Worthing); the determination of impurities in uranium as a means of analyzing complex refractory oxides (Annell and Worthing); the detection of trace amounts of thorium without prior chemical concentration (Waring, Annell, Worthing).

Work continued on the automatic scanning of plates used in the semiquantitative method but mechanical difficulties remain to be solved. 
In the Section's Denver Laboratory the five rock samples collected. for use in tests on new or modified grinding machinery, and from which powders were prepared (see TEIR 182, pp.27-28) have been analyzed quantitatively by Paul Barnett for $\mathrm{Fe}, \mathrm{Cu}, \mathrm{Ni}, \mathrm{Co}, \mathrm{Mn}, \mathrm{Mo}, \mathrm{V}$, and $\mathrm{Cr}$. Uranium is being determined on these samples and a report will be prepared when the results are evaluated in terms of grinding contamination.

Continued evaluation was made of the quality of the spectrographic analyses both in Washington and Denver by the staff of the Spectrography Unit aided by the staff of the Chemistry Unit. Details of this work will be reported here only when enough data have accumulated to be of more than passing significance.

\section{RADIOMETRIC INVESTIGATIONS}

by

Frank Senfte, Francis J. Flanagan, Ray Champion, Jim Bracken, and John W. Rosholt

The work of the Radioactivity Unit has been reorganized by Frank Senftle, who joined the Section staff as Head of the Unit, with headquarters in Washington, during the quarter.

A General Electric Mass-Spectrometer Leak Detector (obtained from surplus some time ago) has been disassembled by Jim Bracken and rebuilt with some modifications. It is proposed to use this instrument for the measurement of helium in rocks when the need arises.

It has been decided to use the thoron method for analysis of small amounts of thorium in rocks and minerals. Other beta-gamma and absorber 
methods which have been ised on more radioactive samples will not give the desired sensitivity on the low-activity samples submitted to the Radioactivity Unit. Ray Champion has completed the components of the apparatus and they are being assembled.

An alpha spectrograph is being constructed by Champion and Bracken to determine whether satisfactory $U$ and Th analyses can be made on very weak samples.

Francis Flanagan and Frank Senftle have started a program to measure the surface adsorption of different radioactive cations on mineral surfaces. It is hoped that such a study will throw some light on the adsorption of radioactive ions on grain surfaces of various minerals. Four radiolsotopes are on order from the Oak Ridge National Laboratory. Natural radio-lead heen isolated from a sample of residue from Eldorado Radium Refining and is being used to develop the technique to be used for these studies.

No work was done during the aquarter on the development of a rapid radiochemical method for the determination of $U$ and Th in monazite (Francis J. Flanagan, Jesse Warr, F.S. Grimaldi).

Progress was made during the quarter by John $W$. Rosholt in the Section's Denver Laboratory on a method of determining the natural radioactivity of samples. This method will differentiate several members of the thorium-uranium radioactive series and will account for the Ioss of equilibrium in most cases (see TEIR 182, pp. 28-29). Data have been collected for a number of samples and are being evaluated. On the completion of this evaluation a report on the subject will be prepared.

The data compiled by Flanagan for southeast phosphates on the comparison between radiometric and chemical uranium determinations made 
In both the Denver and Washington Laboratories are still being statistically analyzed. Similar studies will be made of other materials when time permits.

\author{
REPORTS
}

by. .

Jane Titcomb

Reports issued from October 1, 1951, to December 31, 1951, in the U. S. Geological Survey's Trace Elements Investigations Report and Trace Elements Memorandum Report series are as follows: (This issuance does not constitute publication although some of these reports may be published later.)

TEIR

Title and author

Date

178 Sumnary of current U.S.Geological Survey chemical methods of uranium and thorium analysis, by F. S. Grimaldi.

153A Fluorimetric determination of uranium in shaleș, lignites, and monazites after alkali carbonate separation, by Norma Guttag and F.S.Grimaldi

November

182 Summary of the research work of the Trace Elements Section, Geochemistry and Petrology Branch, for the period July 1 through September 30, 1951, by John C. Rabbitt.

December

TTMR

316 Noninterference of the arsenate ion in the volumetric determination of uranium using the Jones reductor, by J。J.Rowe.

October

317 The identification and lead-uranium ratio ages of massive uraninite from the Shinarump conglomerate, Utah, by I. R. Stieff and T.W. Stern.

October

238 The petrography and uranium content of phosphates from Morocco, by Z.S. Altschuler. 
The following reports were approved for publication by the

Director of the Geological Survey:

A method of determining the age of igneous rocks using the accessory minerals, by E. S: Larsen, Jr., N. B. Keevil, and H. C. Harrison, approved for publication in the Bulletin of the Geological Society of America.

The identification and lead-uranium ratio ages of massive uraninite from the Shinarump conglomerate, Utah, by L. R. Stieff and T. W. Stern, approved for publication in Science.

The following report was pubizhed:

Abstracts of the literature on synthesis of apatites and some related phosphates, by Elizabeth B. Jaffe, U. S. Geological Survey Circular 135, December 1951.

The following reports were in process as of December 31, 1951:

1. Bibliography of metamict minerals, by T. Botinelly

2. Some factors in the differential leaching of uranium and radium in pyritic mines and mine dumps, by George Phair.

3. USGS Bulletin--Contributions to Geochemistry: Methods of analysiss for uranium and thorium developed by the U. S. Geological Survey, edited by F.S. Grimaldi, Irving May, and Jane Titcomb.

4. Further studies of the distribution of uranium in rich phosphate beds of the Phosphoria formation, by M. E. Thompson.

5. A new series of immersion liquids, by Robert Meyrowitz.

6. Addenda to: A study of the critical factors in the "direct" fluorimetric determination of uranium, by Mary $\mathrm{H}$. Fletcher.

7. The fluorimetric determination of uranium in nonsaline and saline waters, by Audrey Pietsch and F. S. Grimaldi.

8. Ion exchange between uranium and calcium in pelletal phosphorite, by $\mathrm{R}$. S. Jones.

9.. The spectrographic determination of trace amounts of lead in zircon and other minerals, by C. L. Waring and Helen Worthing. . 
10. Summary of uranium mineralogy related to deposits studied by the Geological Survey through 1950, by T. Botinelly.

11. A semiquantitative spectrographic method for the analysis of minerals, rocks, and ores (II), by C. L. Waring and C. S. Annell.

12. A volumetric method for the estimation of the oil yield of oil shale, by Frank Cuttitta.

13. A study of the critical factors in the colorimetric determination of total iron in silicates, phosphates, and other nonmetallic minerals with o-phenanthroline, by Frank Cuttitta.

14. Contamination of rock samples during grinding as determined spectrographically, by A. T. Myers and Paul R. Barnett. 


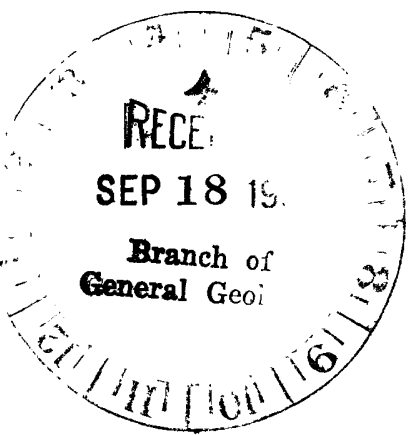

